\title{
Development of Freshly Prepared Phalsa-Pear Blended Beverage
}

\author{
Bharat Bhushan Pangotra $^{1}$, Neeraj Gupta ${ }^{1 *}$ and Arti Sharma ${ }^{2}$ \\ ${ }^{1}$ Division of Food Science and Technology, SKUAST-Jammu, Chatha-180009, India \\ ${ }^{2}$ Division of Fruit science, SKUAST-Jammu, Chatha-180009, India \\ *Corresponding author
}

\begin{tabular}{|l|}
\hline K e y w or d s \\
Phalsa, Pear, Blend, \\
Beverages, Crush
\end{tabular}

\section{Introduction}

Phalsa (Grewia subinaequalis L.), also known as star apple is a subtropical fruit of India. It belongs to the family "Tiliaceae". This family has about 41 genera and 400 species which are mostly distributed in the tropical and subtropical region of the world. In India, it is commercially grown in Punjab, Haryana, Rajasthan, Uttar Pradesh and Madhya
Pradesh. Besides these states, it is also cultivated on limited scale in Maharashtra, Gujarat, Andhra Pradesh, Bihar and West Bengal (Kumar et al., 2014). In Jammu and Kashmir state, it is not cultivated commercially but grown in kandi and dry land areas of Kathua, Samba, Jammu, Udhampur, Rajouri and Reasi districts. From these locations, it could find ready market for disposal. Phalsa fruit is ready for picking in $\mathrm{S}$. 
India from March to April; whereas in $\mathrm{N}$. India it is harvested in the months of May June. The fruits are highly perishable in nature and due to its perishability, it cannot be exported but its processed products are very appreciable. Ripe fruits are consumed fresh in desserts, or processed into refreshing soft drinks like squash, RTS, sharbat etc. which are enjoyed during hot summer months in India.

The attractive crimson red to dark purple colour of phalsa fruit is due to anthocyanin pigments mainly, delphinidin-3-glucoside, cyanidin-3-glucoside and pelargonidin-3, 5 diglucoside. The major phyto-chemical compounds present in the fruit of phalsa are triterpenoids, fatty component, flavonoids (quercetin, quercetin-3-O- $\beta$-D-glucoside and naringenin-7-O- $\beta$-D-glucoside), steroids, saponins and tannins. The fruits possess very high antioxidant activity due to presence of vitamin $\mathrm{C}$, phenolics, flavonoids, tannins and anthocyanin. In the fruit, highest antioxidant activities are found in fruit peel followed by pulp and seeds (Tiwari et al., 2014). Sand pear (Pyrus pyrifolia L.) is an important pome fruit of family "Rosaceae". Pear has lowered acidity, insipid flavor and grittiness, which are the major constraint for its large scale processing. Therefore, owing to presence of such attributes, these fruits are rarely used as fresh or in processing and hence fetch lower price to the grower. Pear fruit is helpful in maintaining acid base balance in human body but the utilization of the hard type of pear (patharnakh) has not received much attention for processing so far. Thus blending of phalsa pulp and pear juice offers many opportunities to develop balanced health product high in quality with respect to both sensory and nutritional aspects

\section{Materials and Methods}

Ripened fruits of Phalsa (Grewia subinaequalis L.) were procured from Raya
Suchani area of district Samba, J\&K and fruits of Pear (Pyrus pyrifolia L.) cv. Patharnakh were procured from revenue orchard of Advance Centre for Horticulture Research (ACHR), Udheywalla, SKUAST-Jammu. Both Phalsa and pear fruits were transported to pilot plant of Division of Food Science and Technology, SKUAST-J, Chatha for further processing. The diseased, defective and unripe fruits were sorted out and thereafter healthy and ripe fruits were retained for extraction of pulp. The phalsa and the pear pulp/juice were blended with each other in different ratios for developing crush (Table 1).

The desired quantity of sugar and citric acid was added in warm water and the solution is strained of through muslin cloth. The solution is added in phalsa-pear blend so as to maintain its total soluble solids as $55{ }^{0}$ Brix and an acidity of 1 per cent. The crush prepared was filled in pre-sterilized glass bottle crown corked, processed for $30 \mathrm{~min}$. in boiling water, cooled immediately, labeled. The blended crush was analyzed for physico-chemical and organoleptic evaluation.

\section{Results and Discussion}

\section{Physico-chemical composition of fresh fruit}

Among most of the fruits; 'phalsa' is very small in size comparable with a pea grain. The fruit however possesses an attractive colour ranging from crimson red to dark purple depending upon its state of maturity. The richness of natural colour is due to plant pigments viz., the anthocyanins in the fruit. This confirms the finding of Khurdiya (1979). The phalsa fruit had an average fruit weight of $0.54 \mathrm{~g}$, whereas pulp and seed cum pomace weight per $100 \mathrm{~g}$ of fruit was 85 and $14 \mathrm{~g}$, respectively. These findings were in conformity with the findings of Yadav (1999). The total soluble solids, acidity and $\mathrm{pH}$ of freshly prepared phalsa pulp were found to be 
$15.50{ }^{0}$ Brix, $1.66 \%$ and 3.50 , respectively, which were in close compliance to the findings of Kaccha et al., (2014), Balaswamy et al., (2011) and Waskar (1985). Reducing sugar, total sugar and ascorbic acid of phalsa pulp were recorded as $12.10 \%, 13.24 \%$ and $8.90 \mathrm{mg} / 100, \mathrm{ml}$ respectively, which were in conformity with the findings of Kumar et al., (2014) and Yadav (1998). Anthocyanin, tannin, iron and phosphorous contents were found to be 74.12, 1.92, 1.05 and 22.20 $\mathrm{mg} / 100 \mathrm{~g}$ which were in accordance with the results of Haq et al., (2013), Elhassan and Yagi (2010), Tiwari et al., (2014) and Yadav (1998). Pear fruit cv. patharnakh recorded an average fruit weight of $105.5 \mathrm{~g}$, juice weight per $100 \mathrm{~g}$ as 63.8 and seed cum pomace as 35 g. These findings were in accordance with the findings of Raj et al., (2011). Total soluble solids, acidity, $\mathrm{pH}$, reducing sugar, total sugar and ascorbic acid and tannin content were found as $12.00{ }^{\circ}$ Brix, $0.24 \%, 3.8,8.72 \%$ and $10.26 \%, 2.80$ and $106.2 \mathrm{mg} / 100 \mathrm{ml}$, respectively were recorded in pear juices which were in close conformity with the findings of Raj et al., (2011), Mahajan et al., (2013), Rani (1981) and Kohli (1979). Pear fruit was found to contain iron and phosphorous content of 0.20 and $10.2 \mathrm{mg} / 100$ $\mathrm{ml}$, respectively (Table 2 ).

Table.1 Detail of treatments

\begin{tabular}{|l|c|c|}
\hline Treatment & Phalsa pulp & Pear juice \\
\hline $\mathbf{T}_{\mathbf{1}}$ & 100 & 00 \\
\hline $\mathbf{T}_{\mathbf{2}}$ & 95 & 05 \\
\hline $\mathbf{T}_{\mathbf{3}}$ & 90 & 10 \\
\hline $\mathbf{T}_{\mathbf{4}}$ & 85 & 15 \\
\hline $\mathbf{T}_{\mathbf{5}}$ & 80 & 20 \\
\hline $\mathbf{T}_{\mathbf{6}}$ & 75 & 25 \\
\hline $\mathbf{T}_{\mathbf{7}}$ & 70 & 30 \\
\hline $\mathbf{T}_{\mathbf{8}}$ & 65 & 35 \\
\hline $\mathbf{T}_{\mathbf{9}}$ & 60 & 40 \\
\hline $\mathbf{T}_{\mathbf{1 0}}$ & 55 & 45 \\
\hline $\mathbf{T}_{\mathbf{1 1}}$ & 50 & 50 \\
\hline
\end{tabular}

Table.2 Physico-chemical composition of fresh fruit of phalsa and pear

\begin{tabular}{|l|l|l|}
\hline Physical parameters & Phalsa & Pear \\
\hline Fruit weight (g) & 0.54 & \\
\hline Pulp weight (g/100 g) & 85.0 & 105.50 \\
\hline Seed cum pomace weight (g/100 g) & 14.0 & 63.80 \\
\hline Chemical parameters & & 35.0 \\
\hline TSS $\mathbf{0}$ Brix & 15.50 & \\
\hline Acidity (\%) & 1.66 & 12.0 \\
\hline pH & 3.50 & 0.24 \\
\hline Reducing sugar (\%) & 12.10 & 3.80 \\
\hline Total sugar $\mathbf{\%})$ & 13.24 & 8.72 \\
\hline Ascorbic acid (mg/100 g) & 8.90 & 10.26 \\
\hline Anthocyanin (mg/100 g) & 74.12 & 2.80 \\
\hline Tannin (mg/100 g) & 1.92 & -- \\
\hline Iron (mg/100 g) & 1.05 & 106.20 \\
\hline Phosphorus (mg/100 g) & 22.20 & 0.20 \\
\hline
\end{tabular}


Table.3 Chemical composition of freshly prepared phalsa-pear blend

\begin{tabular}{|c|c|c|c|c|c|c|c|c|c|c|}
\hline $\begin{array}{l}\text { Ratio of pulp/Juice } \\
\text { Phalsa: Pear }\end{array}$ & $\begin{array}{c}\text { TSS } \\
\left({ }^{0} \text { Brix }\right)\end{array}$ & $\begin{array}{l}\text { Acidity } \\
(\%)\end{array}$ & pH & $\begin{array}{c}\text { Reducing sugar } \\
(\%)\end{array}$ & $\begin{array}{c}\text { Total sugar } \\
(\%)\end{array}$ & $\begin{array}{c}\text { Ascorbic acid } \\
(\mathbf{m g} / 100 \mathrm{ml})\end{array}$ & $\begin{array}{l}\text { Anthocyanin } \\
(\mathrm{mg} / 100 \mathrm{ml})\end{array}$ & $\begin{array}{c}\text { Tannin } \\
(\mathrm{mg} / 100 \\
\mathrm{ml})\end{array}$ & $\begin{array}{c}\text { Iron } \\
(\mathrm{mg} / 100 \\
\mathrm{ml})\end{array}$ & $\begin{array}{c}\text { Phosphorus } \\
\text { (mg/100 } \\
\text { ml) }\end{array}$ \\
\hline $\mathrm{T}_{1}(100: 0)$ & 15.50 & 1.66 & 3.50 & 12.10 & 13.24 & 8.90 & 74.12 & 1.92 & 1.05 & 22.20 \\
\hline$T_{2}(95: 05)$ & 15.00 & 1.41 & 3.52 & 12.07 & 12.94 & 8.62 & 72.10 & 6.95 & 1.01 & 22.11 \\
\hline$T_{3}(90: 10)$ & 14.90 & 1.38 & 3.54 & 11.75 & 12.88 & 8.40 & 67.07 & 11.32 & 0.99 & 21.86 \\
\hline $\mathrm{T}_{4}(85: 15)$ & 14.50 & 1.36 & 3.54 & 11.66 & 12.71 & 7.81 & 64.02 & 16.17 & 0.91 & 21.66 \\
\hline $\mathrm{T}_{5}(80: 20)$ & 14.00 & 1.35 & 3.55 & 11.27 & 12.53 & 7.70 & 61.93 & 21.05 & 0.88 & 21.44 \\
\hline $\mathrm{T}_{6}(75: 25)$ & 13.90 & 1.35 & 3.57 & 10.97 & 12.40 & 7.42 & 57.89 & 26.16 & 0.78 & 20.91 \\
\hline $\mathrm{T}_{7}(\mathbf{7 0 : 3 0 )}$ & 13.80 & 1.32 & 3.60 & 10.83 & 12.25 & 7.10 & 52.65 & 30.92 & 0.73 & 20.64 \\
\hline $\mathrm{T}_{8}(65: 35)$ & 13.30 & 1.26 & 3.63 & 10.55 & 12.14 & 6.78 & 51.66 & 35.96 & 0.69 & 20.34 \\
\hline $\mathrm{T}_{9}(60: 40)$ & 13.30 & 1.18 & 3.65 & 10.43 & 11.99 & 6.50 & 47.61 & 41.44 & 0.66 & 20.04 \\
\hline $\mathrm{T}_{10}(55: 45)$ & 13.10 & 1.06 & 3.68 & 10.20 & 11.72 & 6.20 & 42.55 & 46.51 & 0.61 & 19.88 \\
\hline $\mathrm{T}_{11}(50: 50)$ & 13.00 & 0.96 & 3.70 & 10.15 & 11.61 & 5.88 & 40.50 & 52.89 & 0.59 & 18.96 \\
\hline Mean & 14.02 & 1.29 & 3.58 & 11.08 & 12.40 & 7.39 & 57.46 & 26.48 & 0.80 & 20.91 \\
\hline
\end{tabular}

Table.4 Chemical composition of freshly prepared phalsa-pear blended crush

\begin{tabular}{|c|c|c|c|c|c|c|c|c|c|c|}
\hline $\begin{array}{l}\text { Ratio of pulp/Juice } \\
\text { Phalsa: Pear }\end{array}$ & $\begin{array}{c}\text { TSS } \\
\left({ }^{0} \text { Brix }\right)\end{array}$ & $\begin{array}{l}\text { Acidity } \\
(\%)\end{array}$ & pH & $\begin{array}{l}\text { Reducing sugar } \\
(\%)\end{array}$ & $\begin{array}{c}\text { Total sugar } \\
(\%)\end{array}$ & $\begin{array}{l}\text { Ascorbic acid } \\
(\mathbf{m g} / 100 \mathrm{ml})\end{array}$ & $\begin{array}{l}\text { Anthocyanin } \\
(\mathrm{mg} / 100 \mathrm{ml})\end{array}$ & $\begin{array}{c}\text { Tannin } \\
(\mathrm{mg} / 100 \mathrm{ml})\end{array}$ & $\begin{array}{c}\text { Iron } \\
(\mathrm{mg} / 100 \mathrm{ml})\end{array}$ & $\begin{array}{c}\text { Phosphorus } \\
\text { (mg/100 } \\
\text { ml) }\end{array}$ \\
\hline $\mathrm{T}_{1}(100: 0)$ & 55.0 & 1.0 & 4.16 & 32.62 & 43.51 & 7.38 & 18.92 & 0.43 & 0.31 & 6.87 \\
\hline$T_{2}(95: 05)$ & 55.0 & 1.0 & 4.18 & 32.50 & 43.42 & 7.28 & 18.62 & 1.08 & 0.28 & 6.79 \\
\hline $\mathrm{T}_{3}(90: 10)$ & 55.0 & 1.0 & 4.19 & 32.37 & 43.36 & 7.02 & 18.43 & 1.71 & 0.25 & 6.63 \\
\hline $\mathrm{T}_{4}(85: 15)$ & 55.0 & 1.0 & 4.21 & 32.27 & 43.33 & 6.94 & 18.39 & 1.97 & 0.24 & 6.57 \\
\hline $\mathrm{T}_{5}(80: 20)$ & 55.0 & 1.0 & 4.21 & 32.25 & 42.96 & 6.86 & 17.37 & 2.09 & 0.21 & 6.51 \\
\hline$T_{6}(75: 25)$ & 55.0 & 1.0 & 4.24 & 32.18 & 42.67 & 5.90 & 17.22 & 2.85 & 0.21 & 6.42 \\
\hline $\mathrm{T}_{7}(\mathbf{7 0 : 3 0 )}$ & 55.0 & 1.0 & 4.26 & 32.14 & 42.61 & 5.85 & 16.18 & 3.96 & 0.19 & 6.39 \\
\hline $\mathrm{T}_{8}(65: 35$ & 55.0 & 1.0 & 4.27 & 32.02 & 42.52 & 4.72 & 15.17 & 5.99 & 0.17 & 6.36 \\
\hline $\mathrm{T}_{9}(60: 40)$ & 55.0 & 1.0 & 4.28 & 31.91 & 42.41 & 4.51 & 15.13 & 8.05 & 0.16 & 6.26 \\
\hline$T_{10}(55: 45)$ & 55.0 & 1.0 & 4.30 & 31.80 & 42.20 & 4.12 & 12.92 & 9.47 & 0.15 & 6.21 \\
\hline$T_{11}(50: 50)$ & 55.0 & 1.0 & 4.30 & 31.69 & 42.12 & 4.07 & 10.75 & 12.11 & 0.12 & 6.16 \\
\hline $\operatorname{Sem}( \pm)$ & 0.02 & 0.02 & 0.01 & 0.02 & 0.11 & 0.02 & 0.02 & 0.01 & 0.06 & 0.01 \\
\hline CD (5\%) & NS & NS & 0.03 & 0.07 & 0.33 & 0.07 & 0.08 & 0.05 & NS & 0.05 \\
\hline
\end{tabular}


Int.J.Curr.Microbiol.App.Sci (2018) 7(2): 2870-2876

Table.5 Sensory evaluation of freshly prepared phalsa-pear blended crush

\begin{tabular}{|c|c|c|c|c|c|}
\hline $\begin{array}{l}\text { Ratio of pulp/Juice } \\
\text { Phalsa: Pear }\end{array}$ & Colour & Body & Aroma & Taste & $\begin{array}{c}\text { Overall } \\
\text { acceptability }\end{array}$ \\
\hline $\mathrm{T}_{1}(100: 0)$ & 7.53 & 6.79 & 6.82 & 6.82 & 6.99 \\
\hline $\mathrm{T}_{2}(95: 05)$ & 7.45 & 6.87 & 6.79 & 6.91 & 7.00 \\
\hline$T_{3}(90: 10)$ & 7.41 & 6.95 & 6.87 & 7.06 & 7.07 \\
\hline $\mathrm{T}_{4}(85: 15)$ & 7.38 & 6.98 & 6.53 & 7.32 & 7.05 \\
\hline $\mathrm{T}_{5}(80: 20)$ & 7.72 & 7.34 & 7.45 & 7.44 & 7.48 \\
\hline $\mathrm{T}_{6}(75: 25)$ & 7.31 & 7.29 & 7.19 & 7.35 & 7.28 \\
\hline $\mathrm{T}_{7}(\mathbf{7 0 : 3 0 )}$ & 7.04 & 7.21 & 7.12 & 7.29 & 7.16 \\
\hline $\mathrm{T}_{8}(65: 35)$ & 6.93 & 6.99 & 7.11 & 6.98 & 7.00 \\
\hline $\mathrm{T}_{9}(60: 40)$ & 6.65 & 6.65 & 6.45 & 6.85 & 6.65 \\
\hline$T_{10}(55: 45)$ & 6.44 & 6.23 & 6.12 & 6.75 & 6.38 \\
\hline$T_{11}(50: 50)$ & 6.12 & 6.12 & 6.07 & 6.72 & 6.25 \\
\hline $\operatorname{Sem}( \pm)$ & 0.02 & 0.01 & 0.02 & 0.02 & 0.02 \\
\hline CD (5\%) & 0.06 & 0.05 & 0.06 & 0.07 & 0.06 \\
\hline
\end{tabular}




\section{Chemical composition of fresh phalsa-pear blend}

The data revealed that with an increase of pear content in the blends, TSS decreased from $15.50{ }^{0}$ Brix to $13.00{ }^{\circ}$ Brix. While as per cent titratable acidity decreased from 1.66 to 0.96 per cent while as $\mathrm{pH}$ increased from 3.5 to 3.7. This could be due to the presence of low acidity in the pear fruit. Reducing sugar and total sugar blends also decreased from 12.10 to 10.15 per cent and 13.24 to 11.61 per cent which might be due to lesser concentration in pear juice while as the tannin content of phalsa-pear blends increased from 1.92 to $52.89 \mathrm{mg} / 100 \mathrm{ml}$. As far as ascorbic acid, anthocyanin, iron and phosphorous contents were concerned they decreased from the initials level of 8.90 to $5.88,74.12$ to $40.50,1.05$ to 0.59 and 22.20 to $18.96 \mathrm{mg} / 100$ $\mathrm{ml}$, this might be due to the lower concentration of ascorbic acid, anthocyanin, iron and phosphorous content in pear juice than in phalsa pulp (Table 3). These results were in accordance with the findings of Sharma (2005) and Sharma (2012) who worked on the blending of guava-papaya and jamun-mango, respectively.

\section{Chemical composition of fresh phalsa-pear blended crush}

The total soluble solids and titratable acidity of all the treatments were maintained at $55^{\circ} \mathrm{Brix}$ and 1.0 per cent, respectively. The highest $\mathrm{pH}$ (4.30) was recorded in $\mathrm{T}_{10}$ (55:45:: phalsa: pear) and $\mathrm{T}_{11}(50: 50::$ phalsa: pear $)$ and the lowest (4.16) in $T_{1}$ (100:00:: phalsa: pear). Similar results were reported by Sharma (2012) in jamun-mango squash. The highest and lowest sugars (reducing and total sugar) contents of 32.62, 43.51 and 31.69, 42.12 per cent, respectively were recorded in treatment $\mathrm{T}_{1}$ (100:00:: phalsa: pear) and $\mathrm{T}_{11}$ (50:50:: phalsa: pear). The highest ascorbic acid, anthocyanin, iron and phosphorous contents amounting to $7.38,18.92,0.31$ and $6.87 \mathrm{mg} / 100 \mathrm{ml}$, respectively were observed in $\mathrm{T}_{1}$ (100:00:: phalsa: pear) while lowest $4.07,10.75,0.12$ and $6.16 \mathrm{mg} / 100 \mathrm{ml}$, respectively were observed in treatment $T_{11}$ (50:50:: phalsa: pear). It can be attributed to higher content of ascorbic acid anthocyanin, iron and phosphorous in phalsa fruit than in pear. The maximum and minimum tannin content of 12.11 and $0.43 \mathrm{mg} / 100 \mathrm{ml}$ was recorded in $\mathrm{T}_{11}$ (50:50:: phalsa: pear) and $\mathrm{T}_{1}$ (100:00:: phalsa: pear), respectively (Table 4).

\section{Sensory evaluation of phalsa-pear blended crush}

The highest colour, body, aroma, taste and overall acceptability score of 7.72, 7.34, 7.45, 7.44 and 7.48 , respectively were recorded for $\mathrm{T}_{5}$ (80:20:: phalsa: pear) while as the lowest score of $6.12,6.12,6.07,6.72$ and 6.25 for colour, body, aroma, taste and overall acceptability, respectively were observed by $\mathrm{T}_{11}$ (50:50:: phalsa: pear). Based on the sensory evaluation scores of different attributes, $\mathrm{T}_{5}$ (80:20:: phalsa: pear) ranked on the top and was considered the most suitable ratio for making crush (Table 5).

\section{Acknowledgement}

The corresponding author is grateful to Department of Science and Technology, New Delhi for providing funds under SERB-DST project

\section{References}

Balaswamy, K., Rao, P. P., Nagender, A. and Satyanarayana, A. 2011. Preparation of sour grapes (Vitis vinifera) beverages and evaluation of their storage stability. Journal of Food Processing and Technology, 2: 100-116.

Elhassan, G. O. M. and Yagi, S. M. 2010. Nutritional composition of Grewia 
species (Grewia tenax (Forsk) Fiori, G. flavescens Juss and G. Villosa wild) fruits. Advanced Journal of Food Science and Technology, 2 (3): 159162.

Haq, M. Z., Stankovie, M. S., Rizwan, K. and De Feo, V. 2013. Phalsa (Grewia asiatica L.) food plant with multiple uses. Molecules, 18: 2663-2682.

Kacha, H. L., Jat, G. and Patel, S.K. 2014. Performance of various plant growth regulators on yield and quality of phalsa (Grewia asiatica L.). Horticulture Flora Research Spectrum, 3 (3): 292-294

Khurdiya, D. S. 1979. Nature and retention of anthocyanin pigments in phalsa (Grewia subinaequalis L.) fruit $\mathrm{Ph}$. D. Thesis, IARI, New Delhi

Kohli, A. K. 1979. Studies on the production, preservation and stability of ascorbic acid of patharnakh pear juice. M.Sc. Thesis, Punjab Agricultural University (PAU), Ludhiana.

Kumar, M., Dwivedi, R., Anand, A. K. and Kumar, A. 2014. Effect of nutrient on Physico-chemical characteristics of phalsa (Grewia subinaequalis, L.) fruits. Global Journal of Bioscience and Biotechnology, 3 (3): 32-323.

Mahajan, B. V. C., Kumar, D. and Dhillon, W. S. 2013. Effect of different polymeric films on shelf life and quality of pear fruits under supermarket conditions. Indian Journal of Horticulture, 70 (2): 309-312.

Raj, D., Sharma, P. C. and Vaidya, D. 2011.
Effect of blending and storage on quality characteristics of blending sand pear-apple juice beverage. Journal of Food Science and Technology, 48 (1): 102-105.

Rani, U. 1981. Preparation and storage of pear preserve and pear candy. M. Sc. Thesis, Punjab Agricultural University (PAU), Ludhiana.

Sharma, D. 2012. Processing of jamun (Syzygium cumini L.) into value added products. Ph.D Thesis, Division of PHT, SKUAST- Jammu, India.

Sharma, I. 2005. Preparation and evaluation of ready-to-serve beverage from guava and papaya. M. Sc. Thesis, Division of Pomology and Post-Harvest Technology, SKUAST- Jammu, India.

Tiwari, D. K., Singh, D., Barman, K. and Patel, V. B. 2014. Bioactive compounds and processed products of phalsa (Grewia subinaequalis L.) fruit. Popular Kheti, 2 (4): Sept-Oct.

Waskar, D. P. 1985. Processing and storage of phalsa beverages. M.Sc. Thesis, Indian Agricultural Research Institute (IARI), New Delhi.

Yadav, A. K. 1998. Phalsa: Commodity sheet FVSU-004 of the Fort Valley State University. Agriculture Research Station.

Yadav, A. K. 1999. Phalsa: A potential new small fruit for Georgia. In: Janick, J (Ed.), Perspectives on New Crops and New uses. ASHS, pp 348-352.

\section{How to cite this article:}

Bharat Bhushan Pangotra, Neeraj Gupta and Arti Sharma. 2018. Development of Freshly Prepared Phalsa-Pear Blended Beverage. Int.J.Curr.Microbiol.App.Sci. 7(02): 2870-2876. doi: https://doi.org/10.20546/ijcmas.2018.702.350 